\title{
Microfinance Strengthening Analysis: Strategic HRM and Innovation Performance in Processing Industry in Makassar
}

\author{
Idayanti Nursyamsi \\ Economic and Business Faculty, Hasanuddin University, Makassar, Indonesia \\ Idayanti_uh@yahoo.com \\ Ria Mardiana \\ Economic and Business Faculty, Hasanuddin University, Makassar, Indonesia \\ riamard@unhas.ac.id
}

This paper aims to analyze the direct and indirect effect of strategic human resource management on performance innovation and microfinance strengthening in processing industry in Makassar. This research also tests four hypotheses in the research concept. Research design uses causality concept to measure causality relationship among variables in the research construct. Structural equation modeling with PLS tool and nonprobability sampling method was used in this study. The research sample consists of 54 heads of processing organizations and the businesses owners. The results show that there is a significant direct effect relates to the strategic human resource, directly and indirectly, effect to the strengthening microfinance organizations. However, the strategic human resource has no significant effect on microfinance strengthening in the processing industry in Makassar.

Keywords: Strategic human resource management, performance innovation, microfinance strengthening.

\section{INTRODUCTION}

Microfinance is an organizational institution engaged in the field of service providers. This organization may consist of government banks, traditional banks, and private banks. This service provider provides credit application services in various fields of small and medium enterprises. Financial service providers are in the form of assisting the acceleration of small and medium industries to be more marketable and profitable. In addition to financial services, risk management protection is also a major concern using insurance services as a main characteristic of service provided to customers. Microfinance helps customers who are in low-income positions using profitable programs viewed from economic aspects in order to minimize loss of assets owned by customers.

Microfinance is a rapidly growing field of industry in the current decade. Social contributions of microfinance have a positive effect on the development of entrepreneurship for a nation. This gives various nuances to investment opportunities and challenges in realizing the prosperity of the State. The important role of investment, the utilization of appropriate technology, innovations that provide business performance improvement are also some major points.

Microfinance's problems were presented by Nasir (2013) in terms of external aspects such as high lending rates, lack of client commitment, low level of education, language barriers, late payments, geographic factors and low debt repayment management. Furthermore, internal issues include the high cost of transaction fee administration, the existence of agency costs, mismanagement fraud, loan collection methods, population 
density, challenges, quality, regional disparities, low research on microfinance topics, external environment, low rate of microfinance growth, low regulatory institutions, insurance coverage is still low. Those findings were reinforced by Doreen (2014) and stated that internal aspects of microfinance require serious attention in terms of interest rates, repayment periods, repayment amounts and penalty charges.

In terms of human resources aspect, microfinance problem is the part of customers aspect who generally still have the source of funds as capital in a low amount. It is generally within the scope of the home industry, housewives, farmers, traders, or commonly known as small and medium enterprises. Small and medium enterprises do not only weak in accessing capital resources, they also have the low capability of running a business, such as do not know how to apply the appropriate credit to the bank, and credit risk applications that have not been understood. Therefore, human resource skills must be well prepared, because their human resources competence has not been sufficient, lack support capacity of personnel management, work ethic and a work commitment of human resources need were not be designed well yet.

The existence of various challenges in the form of economic movement, globalization, domestic differences, technology has brought a new demand for organizations. The gained challenges will create opportunities for human resources management and organizations comprehensively, hence its require to examine challenges and opportunities that may affect the future of human resources management (Stone, Dianna, L and Deadrick, Diana L, 2015).

Problems in the practice of human resources management can be caused by choice, education, performance evaluation, promotion, reward, information sharing, and security in work (Pasaoglu, Didem, 2015). Other problems can be caused by strategic human resources management, weak cultural innovation, weak employee ownership, and weak employee innovation performance (Tuna, Uslu, 2015., Aryanto, Riza., Fontana, Avanti., Afiff, Adi Zakaria, 2015, Zehir, Cemal., Gurol, Yonca., Karaboga, Tugba., Kole, Mahmut, 2016. Hecklau, Fabian., Galeitzke, Mila., Flaschs, Sebastian., Kohl, Holger, 2016, Allui, Alwiya and Sahni, Jolly, 2016).

Utilization of human resources in the microfinance field can help customers in handling microfinance problems better, especially in the food and beverage industry in Makassar. Likewise, less optimal handling of microfinance may cause above problems, and may bring about the microfinance sector cannot grow significantly in Indonesia. The above problems encourage researcher to assess the readiness of human resources so that more ready to be empowered more effectively in the microfinance field.

\section{HRM Strategy and Innovation Performance Effect on Microfinance Strengthening}

Aryanto, Riza., Fontana, Avanti., Afiff, and Adi Zakaria (2015) in the study "Strategic Human Resources Management, Innovation Capability, and Performance: An Empirical Study in Indonesia Software Industry" found that companies should develop innovation capabilities to manage innovation processes from the generalization of the idea to the commercialization stage. Human resources management strategy is one of the key determinants of the human resource management innovation process. The results of the study suggest that strategic human resource management practices are positively related to innovation capabilities and have a positive effect on the innovation performance.

Zehir, Cemal., Gurol, Yonca., Karaboga, Tugba., Kole, and Mahmut (2016) in the study "Strategic Human Resource Management and Firm Performance: The Mediating Role of Entrepreneurial Orientation" examines the topic of strategic human resource management and entrepreneurship activities within the organization. The literature review examines and 
analyzes the strategic human resource management aspects of organizational performance mediated by entrepreneurial factors. Research findings indicate a link between strategic human resource management and organizational performance mediated by entrepreneurial factors.

An important role of strategic human resources management contributes to key positive and significant contributions to the organization (Usla, Tuna, 2015; Pasaoglu, and Didem, 2015). The need for more attention and increasingly needed factors Strategic Human Resources Management (Allui, Alwiya and Sahni, Jolly, 2016).

Based on those empirical facts, the hypothesis is proposed as follows:

H1: HRM Strategy has a significant effect on Microfinance Strengthening

H2: HRM Strategy has a significant effect on Innovation Performance

H3: Innovation performance has a significant effect on microfinance strengthening

H4: HRM strategy has a significant effect on strengthening microfinance through innovation performance.

\section{RESEARCH METHODS}

\section{Research model}

Based on the background, research problems and objectives, the research model can be described as follows:

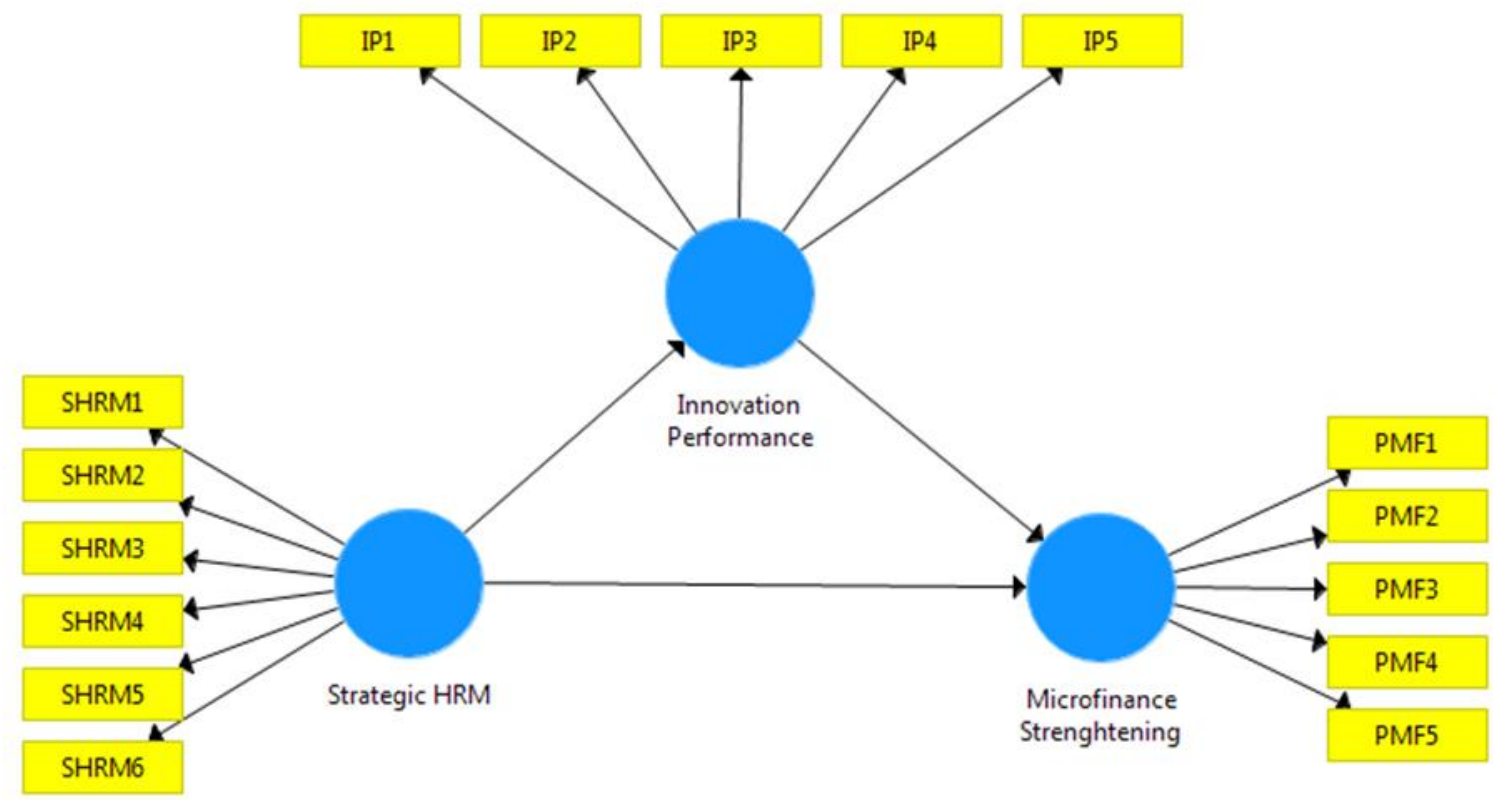

Figure 1

Conceptual Research Framework

Source: Aryanto, Riza., Fontana, Avanti., Afiff, Adi Zakaria (2015); Zehir, Cemal., Gurol, Yonca., Karaboga, Tugba., Kole, Mahmut (2016); Usla, Tina (2015); Pasaoglu, Didem (2015) (Allui, Alwiya and Sahni, Jolly, 2016). 
The figure 1 above explains the effect of HRM strategy and innovation performance on microfinance strengthening.

\section{Sample and Data Analysis Techniques}

The samples of this research are 54 food and beverage industries in Makassar. The design of this study using the concept of causality research that measures the extent to which relationships between one variable with other variables. Structural Equation Model (SEM) analysis was used with SMARTPLS3 analysis method. The sampling technique uses nonprobability sampling method or nonrandom sampling method with accidental sampling technique. Research sampling was assisted using manual questionnaire.

\section{Variable Measurement}

The variables in this study are HRM strategy, innovation performance, and microfinance strengthening. Microfinance strengthening is translated into six indicators adapted from Doreen, Makandi (2014). The indicators are saving, credit, assurance, and retirement.

The HRM strategy is outlined into 5 indicators adapted from Uslu, Tuna (2015); Aryanto, et al (2015) and Zehir, et al (2015). The indicators are human resource planning, human resource acquisition, human resource development, human resource performance management and reward management.

Innovation performance is translated into 7 indicators adapted from Zehir, Cemal, et al (2016). The indicators are financial performance, employee performance, internal performance, technical performance, commercial performance, economic performance, and social performance.

\section{RESEARCH RESULT AND DISCUSSION}

\section{Analysis with PLS Method}

In this section, the analysis is done through the designed path diagram of the influence analysis of HRM Strategy and innovation performance variables on microfinance strengthening. The first step in PLS modeling is the specification model in the research that will be conducted. There are two kinds of specification model, designing inner model and outer model. Inner model is a structural model that connects among latent variables in substantive theory, such as variable $\mathrm{X}$ (exogenous) to variable $\mathrm{Y}$ (Endogen). The exogenous variables $(\mathrm{X})$ in this study is the: HRM Strategy, whereas the endogenous variables $(\mathrm{Y})$ in this study, is the innovation performance and microfinance strengthening. The path diagram of data processing using Smart-PLS (Partial Least Square) software can be seen in Figure 2 below. 


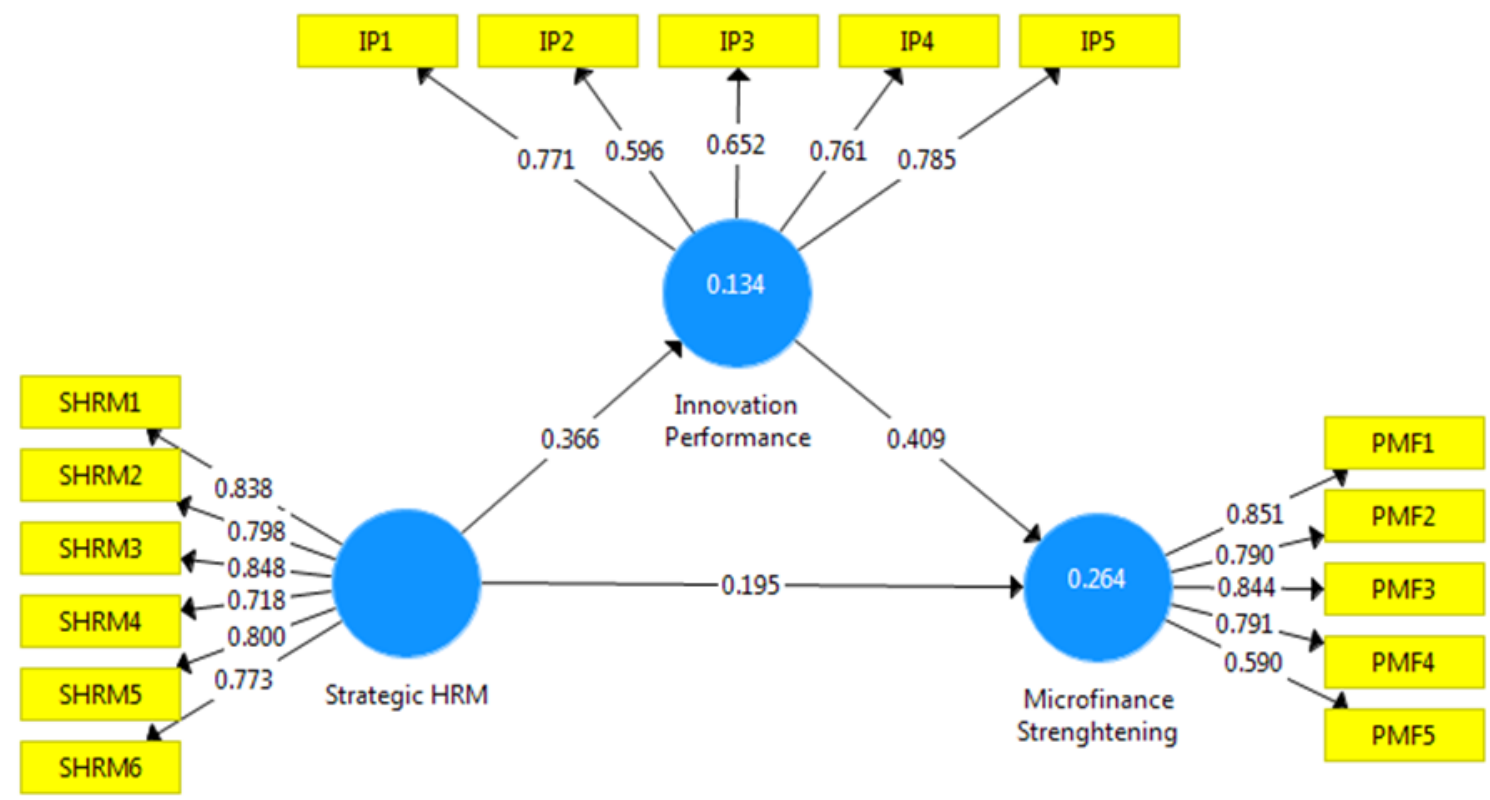

Figure 2

Construction Line Diagram Results PLS Modeling

Source: data processed for this study (2017)

From the analysis result of PLS modeling in figure 2, there are indicators that do not meet the rule of thumb of convergent validity which has a value of factor loading below 0.7 , such as IP2 (0.596), IP3 (0.652) and PMF $(0,590)$ so that eliminate the indicator and modified the model. The results of the modification of the PLS analysis model can be seen in Figure 3 .

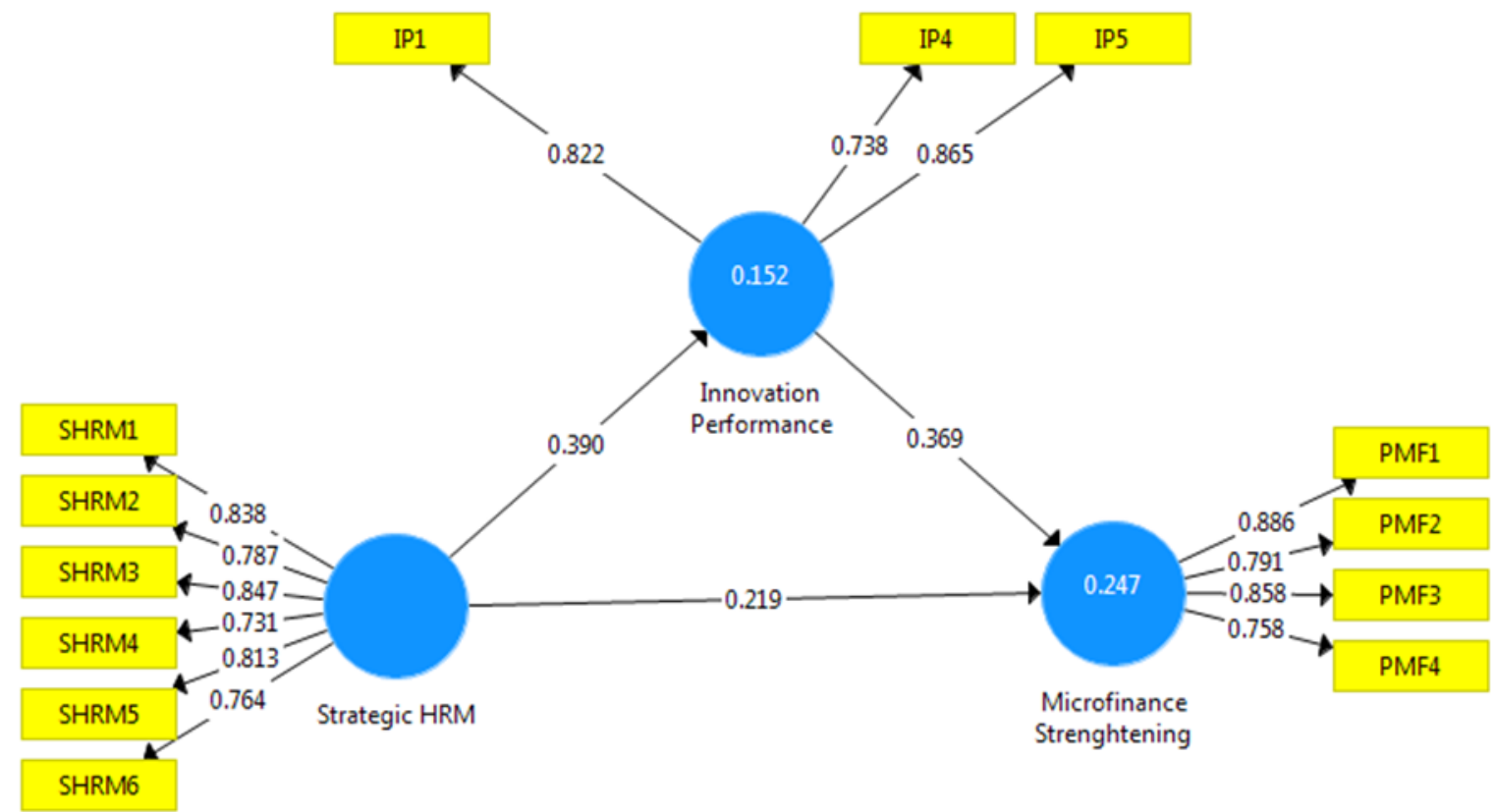

Figure 3

Construction Line Diagram Result Modeling PLS After Modified

Source: data processed for this study (2017)

\section{Evaluation of Goodness of Fit Criteria}

\section{Evaluation Result of Goodness of Fit on Outer model}


Evaluation of the Goodness of Fit on outer models with reflective indicators evaluated by convergent validity, discriminant validity, and composite reliability with the following results:

\section{Convergent validity}

Convergent validity in PLS with reflective indicators is seen based on loading factor value (correlation between item score/component score and construct score). The output of convergent validity can be seen in Table 1 .

Table 1

Test Result of Convergent Validity

\begin{tabular}{|l|c|c|c|}
\hline \multicolumn{1}{|c|}{ Variable } & Indicator & Loading factor & Remark \\
\hline HRM Strategy & SHRM1 & 0,838 & Valid \\
\cline { 2 - 4 } & SHRM2 & 0,787 & Valid \\
\cline { 2 - 4 } & SHRM3 & 0,847 & Valid \\
\cline { 2 - 4 } & SHRM4 & 0,731 & Valid \\
\cline { 2 - 4 } & SHRM5 & 0,813 & Valid \\
\cline { 2 - 4 } & SHRM6 & 0,764 & Valid \\
\hline Innovation & IP1 & 0,822 & Valid \\
\cline { 2 - 4 } & IP4 & 0,738 & Valid \\
\cline { 2 - 4 } & IP5 & 0,865 & Valid \\
\hline Microfinance & PMF1 & 0,886 & Valid \\
\cline { 2 - 4 } & PMF2 & 0,791 & Valid \\
\cline { 2 - 4 } & PMF3 & 0,858 & Valid \\
\cline { 2 - 4 } & PMF4 & 0,758 & \\
\hline
\end{tabular}

Source: Primary data processed for this study (2017)

Based on table 1 above, all indicators are valid with loading factor value above 0.7 .

\section{Composite reliability}

Composite reliability is a reliability test in PLS which shows accuracy, consistency of accuracy of a measuring instrument (Jogiyanto and Abdillah, 2009). Composite reliability is good if it has a value of more than 0.7 . The results of composite reliability can be seen in Table 2.

Table 2

Testing Result of Discriminant validity

\begin{tabular}{lc}
\hline \multicolumn{1}{c}{ Variable } & $\begin{array}{c}\text { Composite } \\
\text { reliability }\end{array}$ \\
Strategi HRM & 0,851 \\
Innovation Performance & 0,894 \\
Penguatan Microfinance & 0,913
\end{tabular}

Source: Primary data were processed for this study (2017)

Table 2 above shows that all variables are reliable with $\mathrm{CR}$ value $>0.7$.

\section{Evaluation Result of Goodness of Fit on Inner model}

The Goodness of Fit on the inner model is evaluated using R-square dependent latent variables and uses Q-square predictive relevance to show that the constructs used have good 
predictive relevance and are feasible for use in the study. The Q-square value should be >0 were indicating the model has good predictive relevance (Ghozali, 2006). The R-square value of the analysis using Smart-PLS software was 0.152 for innovation performance and 0.247 for microfinance strengthening. This means that the model formation of innovation performance research can be explained well by HRM strategy variable with a value of $15.20 \%$ while $84.80 \%$ is explained by other variables. Furthermore, the formation of the model of microfinance strengthening research can be explained well by HRM strategy variables and innovation performance with a value of $24.70 \%$, while $75.30 \%$ explained by other variables.

Next, the R2 gain is incorporated into the following Q-square equation:

$$
\begin{aligned}
\mathrm{Q} 2 & =1-\left(1-\left(\mathrm{R}_{1}{ }^{2}\right)\left(1-\mathrm{R}_{2}{ }^{2}\right)\right. \\
& =1-(1-0,023)(1-0,061) \\
& =1-(0,977)(0,939) \\
& =1-0,917 \\
& =0,083
\end{aligned}
$$

Based on the result of calculation of Q-square value can be seen that the value of Qsquare is 0.083 or Q-square predictive relevance $=8.3 \%$

\section{Hypothesis testing}

Hypothesis testing is done by comparing t-statistic with t-table. Comparison of $\mathrm{t}$ statistic with t-table is used to know whether or not influence between variables. The thing value is obtained from bootstrapping with Smart-PLS software. Testing with bootstrap also aims to minimize the problem of data abnormalities research (Ghozali, 2006). The t-table value for this study was 1.96 ( $\operatorname{sig} 0.05$ and $\mathrm{df}=95$ ).

Based on hypothesis test result, the direct effect of HRM strategy on microfinance strengthening obtained by t-statistic equals to 1,946 , so it can be concluded that HRM strategy has an insignificant positive effect on strengthening microfinance. The direct effect of the HRM strategy on innovation performance obtained t-statistics of 3,486, so it can be concluded that the HRM strategy has a significant positive effect on innovation performance. The direct effect of innovation performance on microfinance strengthening obtained t-statistic of 3,135 , so it can be concluded that innovation performance has a significant positive effect on microfinance strengthening. The indirect effect of HRM strategy on microfinance enhancement through innovation performance was obtained t-statistic of 2.096, so it can be concluded that HRM strategy has a significant effect on microfinance strengthening through innovation performance.

\section{DISCUSSION}

The findings indicate that there is a direct significant effect of SMEs decision in the food and beverage processing industry on the innovation of their performance. These findings are in line with findings by Zehir, Cemal., Gurol, Yonca., Karaboga, Tugba., Kole, and Mahmut (2016). Food and beverage processing industries in Makassar generally have implemented various strategies to human resources owned, in order to encourage their innovation. That is a strategy that has been implemented by planning various development of HRM organizations. Among them, that requires human resources organizations to join training for their competence improvement. Especially packaging quality training, more 
professional production processes, and implementing policies for more professional rewards. In addition, the average of food and beverage processing industry frequently evaluate the progress and work behavior of the organization's human resources.

Another finding in this study is the indirect effect of HRM strategy on microfinance or micro, small, and medium enterprises (MSMEs) of food and beverage processing industry in Makassar. This finding is in line with the findings of Uslu, Tuna (2015) Nursyamsi, Idayanti and Hamid Nurjannah (2013) who found that innovation has a significant effect on human resource organization strengthening. Based on the interviews results and respondents' answers in regards innovation performance, it is found that basically the organizations provide freedom and flexibility to their human resources in order to perform various innovations in providing services to their customers. In addition, it seems that the company does not think that ideas and innovations become a barrier that will destroy the company.

In contrast, the effect of HRM strategy on the strengthening of MSMEs is not significant. This shows that the implementation of MSME strategy in treating their human resources is still limited in conventional methods strategies. Consequently, food and beverage processing organizations are characterized by family ownership. Hence, their employees are also mostly from their family. This phenomenon leads to corporate HR management strategies become more unique and unlike the strategy of a company with pure private ownership which has multiple shareholders. Generally, UMKM actors are also the owner of the company, especially in the food and beverage processing industries as the object of this study. Hardy et al. (2002) found that MSMEs have special characteristics, among others; management is more closed because of the character of family ownership. This closed management style may cause their HR management strategy cannot be optimally in the sense that ideas and innovations are lacked attention to strengthen the organizational structure. Although applied human resource strategy was found to have an indirect effect through the mediation of innovation, the specification of the human resource strategy implementation was still not optimal, hence it has not provided the basic structure of UMKM itself, particularly in the food and beverage processing industry in Makassar.

\section{CONCLUSION}

Based on the results of data processing, can be concluded that:

1. Human Resource Management (HRM) strategy has an insignificant positive effect on microfinance strengthening.

2. Human Resource Management (HRM) strategy has a significant positive effect on innovation performance.

3. Innovation performance has a significant positive effect on microfinance strengthening.

4. HRM strategy has significant positive effect on microfinance strengthening through innovation performance.

\section{REFERENCES}

Allui, Alwiya dan Sahni, Jolly, 2016. Strategic Human Resource Management in Higher Education Institutions: Empirical Evidence From Saudi. 12 th International Strategic 
Management Conference, ISMC, 28-30 October 2016, Antalya. Procedia Social and Behavioral, 235 (20160. Hal 361-371

Aryanto, Riza., Fontana, Avanti., Afiff, Adi Zakaria. 2015. Strategic Human Resources Management, innovation Capability and performance. 2 nd Global Conference on Business and Social Science, GCBSS, 17-18 September, Bali, Indonesia. Procedia Social and Behavior Sciences, 211(2015), hal 874-879

Doreen, Makandi Ndereba. 2014. Effect of microfinance Credit Terms On performance Of Small and Medium Enterprises. (Case Study of Mombasa County). A Research Project Submitted To The Departement Of Business Studies in Partial Fulfillment of Requirement For The Award of bachelor Of Commerce - Finance Option Of the Technical University Of Mombasa. April

Ghozali, I. (2006) Structural equation modeling, Metode Alternatif dengan Partial Least Square. Edisi 1. Semarang: Badan Penerbit Universitas Diponegoro

Hecklau, Fabian., Galeitzke, Mila., Flachs, Sebastian, 2016. Holistic Approach for Human Resouces Management in Industry 4.0. 6 th CLF- $6^{\text {th }}$ CIRP Conference on Learning Factories. Procedia CIRP 54(2016). Hal 1-6

Jogiyanto, H.M dan Willy, A. (2009) Konsep dan Aplikasi PLS (Partial Least Square) Untuk Penelitian Empiris. Yogyakarta: BPFE Fakultas Ekonomika dan Bisnis UGM

Nasir, Sibghatullah. 2013. microfinance in India: Contemporary Issues and Challenges. Middle -East Journal of Scientific Research.Department of Commerce, AMU, Aligarh, India, IDOSI Publication, 15(2), hal 191-199

Pasaoglu, Didem. 2015. Analysis of The Relationship Between Human Resources Management Practices and Organizational Commitment from Strategic Prespective: Finding From The Banking Indutsry. $11^{\text {th }}$ International Strategic Management Conference. Procedia Social and Behavioral Sciences 207 (2015), hal 315-324

Stone, Dianna, L dan Deadrick, Diana L, 2015. Challenges and Opportunities Affecting The Future of Human Resource Management. Journal of Human Resource Management. Elseiver

Uslu, Tuna. 2015. innovation Culture and Strategic Human Resource Management in Public and Private SectorWithin The Framework Of Employee Ownership. World Conference on Technology, innovation and Entrepreneurship. Procedia Social and Behavior Sciences 195 (2015) hal 1463-1470

Zehir,Cemal., Gurol, Yonca.,Karaboga, Tugba.,Kole, Mahmut, 2016. Strategic Human Resources Management and Firm performance: The Mediating Role Of Entrepreneurial Orientation. Procedia Social and Behavior Sciences.28-30 October 2016 